\title{
The Influence of Motivation and Competence Factors on Lecturers' Performance in Universitas Negeri Surabaya
}

\author{
Sri Handajani, Imami Arum Tri Rahayu, Octaverina Kecvara Pritasari \\ Department of Home Economics \\ Universitas Negeri Surabaya \\ Surabaya, Indonesia \\ srihandajani@unesa.ac.id
}

\begin{abstract}
This research aims to analyze the influence of competence and motivation on lecturers performance is in the home economics department of Universitas Negeri Surabaya. The data obtained through questionnaire and analyzed for multiple regression through Statistical Social Science Program (SPSS). The results show that the competence and motivation variables partially have a significant effect on performance. This research supports the efforts to improve lecturers' performance.
\end{abstract}

Keywords: motivation, competence, and performance

\section{INTRODUCTION}

Teachers or lecturers regarded as the most vital schoolbased factor that influences students' achievement levels. Competence is an important to master by each lecturer and the performance of lecturers affected by the work competence. The previous studies of students' academic performance discussed by AL-Mutairi and Kang'ahi et. al indicates that the lecturer's competence is one of the major elements of the students' academic achievements [1,2]. Lecturer's competence in teaching process is a multidimensional concept to measure the aspects of sharing the knowledge with the students that include communication skills, subjects' expertise, lecturer attendances, teaching skills and lecturer's attitude [3].

Teaching is a collaborative process which encompasses interaction by both learners and the lecturer [4,5]. Lecturers are required to provide maximum educational services to students that based on student satisfaction itself. Through the satisfaction, students expected to be motivated to improve their learning achievements continuously.

The assessment of the lecturers' performance has to done because it covers the process of the organization to evaluate the employee's performance in order to develop the quality of the university. Performance assessment is the periodic purposes of the operational effectiveness of an organization and personality based on the strategy of the goals, standards and performances. The consistent evaluation towards the lecturer's competence factor is important because practically the lecturer's competence measured with the students' academic achievements. [6,7]. In university, lecturer evaluation is a way to know the influence of the teaching towards the students [8]. Specifically, the purpose of the lecturer's performance evaluation is to improve the quality of teaching, the lecturers' identity, students' satisfaction on teaching, lecturers' satisfaction on a profession, and achieve the purpose of the study program. In addition, it increases public's positive judgments toward faculty/university.

Lecturer's performance improvement cannot separate from the supporting factors. The variables that affected the performance of the lecturers are individual variables, such as attitude, characteristics, physical characteristics, interests, motivation, experience, age, gender, education, etc. Whereas, the situational variables include physical, social, and organizational factors of work. Motivation is also one of the factors that affect employee's performance $[9,10]$.

Motivation is a key concept on the understanding the reasons of human behaviour arising, continuity, disappearance or variation among people [11]. The quality of human motivation including the lecturer influenced by intrinsic and extrinsic or external factors. External motivation as a result of Parfyonova's research that individuals partially understand the demand as the value of an activity but they do not regard it as a personal demand, so they act to avoid the feelings of guilt or shame [12]. Intrinsic motivation occurs when task interests drive a person and it does not need to give the external factors $[13,14]$. Lecturer in doing his work has a tendency as described by Mc. Gregor that humans such as $\mathrm{X}$ theory and the $\mathrm{Y}$ theory are essentially human beings tend to behave positively. Hence, the need for motivation to their employees [15]. Motivation is a chain that starts with the needs, causes the desire, causes action, and produces a decision.

Based on the description, the researcher focused on the performance of Home Economic Department's lecturers of Faculty of Engineering at Universitas Negeri Surabaya. The purpose of this study is to determine the influence of competence and motivation on the performance of lecturers in the home economics department of Engineering Faculty at Surabaya State University.

\section{METHODS}

The study was conducted based on descriptive survey and correlational designs. A survey design was chosen to ensure 
collection of information that specifically describes the nature of prevailing conditions at a specific point in time [16]. This quantitative descriptive research has three variables. Independent variable consisting of competence (X1), motivation (X2) and a dependent variable that was lecturer performance $(\mathrm{Y})$. The data collected from lecturers and students at Home Economic Department of Engineering Faculty at Universitas Negeri Surabaya from May to August 2017. Students as the respondents assessed the lecturer's performance and competence taken by random sampling, while the lecturers filled the work motivation. For the assumption, four students assessed by a lecturer and the number of lecturers assessed were 34 people, so that the number of students who filled the questionnaire was 136 people. Questionnaires used to collect data on motivation, performance and competence using a Likert scale with value 5 to 1. Multiple Regression using Statistical Program Social Science (SPSS) analyzed further data.

\section{RESULTS AND DISCUSSION}

\section{A. Results}

The following were a description of lecturer demographic characteristics:

\section{TABLE 1. LECTURER DEMOGRAPHIC CHARACTERISTIC}

\begin{tabular}{|c|c|c|c|}
\hline \multicolumn{2}{|c|}{ Characteristic } & Frequency & Percentage \\
\hline Age & $<25$ year & 0 & 0 \\
& $26-30$ year & 3 & 8.82 \\
& $31-35$ year & 1 & 2.94 \\
& $36-40$ year & 4 & 11.77 \\
& $41-45$ year & 4 & 11.77 \\
& $46-50$ year & 6 & 17.64 \\
& $51-55$ year & 5 & 14.71 \\
& $>56$ year & 11 & 32.35 \\
\cline { 2 - 4 } Gender & Total & 34 & 100 \\
& Man & 2 & 5.88 \\
& Woman & 32 & 94.12 \\
\cline { 2 - 4 } & Total & 34 & 100 \\
\hline Last Education & S1 & 0 & 0 \\
& S2 & 27 & 79.41 \\
& S3 & 6 & 17.65 \\
& Profesor & 1 & 2.94 \\
& Total & 34 & 100 \\
\hline years of service & $<1$ year & 0 & 0 \\
& $1-<5$ year & 5 & 14.71 \\
& $5-<10$ year & 1 & 2.94 \\
& $10-<15$ year & 5 & 14.71 \\
& $15-<20$ year & 1 & 2.94 \\
& $20-<25$ year & 6 & 17.64 \\
& $\geq 25$ year & 16 & 47.06 \\
\cline { 2 - 4 } & Total & 34 & 100 \\
\hline
\end{tabular}

Source: Home Economics Department- Universitas Negeri Surabaya, 2017

The characteristic data in Table 1 showed that lecturers over 45 years old who are mostly women dominated the most lecturers showed $64.7 \%$. Most of the lecturers were having the master degree showed $79.41 \%$, the lecturers were having doctoral degree showed $17.65 \%$, and only one person became a professor. Based on experience or working period, most of the lecturers have experienced in teaching over 15 years as many as 23 people or $67.65 \%$. Based on the results of data management, the regression equation in this study was:

TABLE 2. RESUlt of MULTIPLE LINEAR REGRESSION TEST

\begin{tabular}{|c|c|c|}
\hline VARIABLE & $\begin{array}{c}\text { Coefficient } \\
\text { Regression }\end{array}$ & Significance \\
\hline (Constant) & $-0,627$ & 0,167 \\
\hline Competence.X1 & 0,717 & 0,000 \\
\hline Motivation.X2 & 0,506 & 0,010 \\
\hline$F_{\text {count }}$ & \multicolumn{2}{|c|}{134.806} \\
Significance & \multicolumn{3}{|c|}{000} \\
Multiple correlations (R) & \multicolumn{3}{|c|}{0.897} \\
Coefficient of determination $\left(\mathrm{R}^{2}\right)$ & \multicolumn{2}{|c}{0.897} \\
\hline
\end{tabular}

Source: Data processed

The regression coefficient of competence variable (X1) equal to 0.717 indicates that every increase of performance variable because of the competence $(\mathrm{X} 1)$. Hence, it said that competence increase when performance increase with regression coefficient 0,717 and assuming other variable constant. The regression coefficient of motivation variable (X2) of 0,506 indicates that every increase of performance variable because of competence (X2), then it is said the motivation increase when performance also increases with regression coefficient 0.506 and with other variable assumption constant.

The value of $\mathrm{R} 2$ or coefficient of determination was 0.897; this means that the competence and motivation affect the performance of lecturer (Y) was 0.897 or $89.7 \%$ while other was 0.113 or $11.3 \%$ influenced by other variables outside the independent variable used in research. The value of $\mathrm{R}$ or the correlation coefficient of 0.939 , this means that the competence and motivation correlated very strong to the performance (Y) with a coefficient of 0.947.

The test results showed the value of $F$ was 134.806 with the significance level of $F$ test with $0.000(p<0.05)$ means the competence and motivation significantly influence the performance. Hence, it could be said $\mathrm{Ha}$ accepted the truth. Then t-test was done to determine the influence of each independent variable partially to the dependent variable.

TABle 3. DeCision MAKING FROM TEST RESUlt $\mathrm{t}_{\text {count }}$

\begin{tabular}{|c|c|c|}
\hline Variables & Significance & Information \\
\hline Competence & $0.000 \leq 0,05$ & significant \\
\hline Motivation & $0.001 \leq 0,05$ & significant \\
\hline
\end{tabular}

Source: Data processed

The hypothesis of this study proved significant that the variable competence and motivation partially have a significant effect on performance.

\section{B. Discussion}

The findings of this study clearly showed that characteristics and motivation are partially significant to 
performance; competence and motivation have a significant effect on performance.

Competence affects the performance of lecturers with significant value 0.000 . Based on the significance value of 0.05 or $95 \%$ confidence level can state that the partial hypothesis of research proved true that the competence has a positive and significant effect on the performance of lecturers. Thus, the higher the competence, the lecturer will have better productivity. Lecturers must master competence, in accordance with research of Jusmin, et al., that lecturer has the ability to perform their duties obtained from experience and teaching-learning process and contributes $72.40 \%$ in explaining the lecturer competence. The value of the standardized regression estimate 0.465 with positive direction means that high lecturer competence tends to improve the lecturer's performance and the evidence is the critical ratio value $=3.333>2.00$ and probability value of $0,000<\alpha=$ 0,05 . The result proves that lecturer competence has a positive and significant effect on lecturer performance because lecturer has ability and knowledge of computer technology to affect their ability to perform supporting activities. Lecturers' competencies include pedagogic competence, professional competence, personal competence and social competence.

Pedagogic competencies include an understanding of teachers to learners, design and implementation of learning, evaluation of learning outcomes, and development of learners to actualize the various potentials. Personality competence is a personal ability that reflects a steady, stable, mature, wise, and authoritative personality, a role model for learners, and moral character. Social competence is the ability of teachers to communicate and socialize effectively with learners, fellow educators, education personnel, parents of the students, and the surrounding. Professional competence is a mastery of learning materials in a broad and deep, which includes the mastery of curriculum material subjects in schools and scientific substances that overshadow the material, and the mastery of the structure and methodology of science. The four competencies mentioned above are holistic and integrative in teacher performance.

Therefore, the whole figure of teacher competence includes the introduction of learners in depth, the mastery of both disciplinary content and teaching materials in the school curriculum, the provision of educational learning that includes the planning and implementation of learning, evaluation of processes and learning outcomes, and follow-up for improvement and enrichment. In addition, continuous development of personality and professionalism is also the consideration of the teacher competence figure. Teachers who have the competence will be able to perform their duties professionally.

According to the Law of the Republic of Indonesia No. 14,2005 on teachers and lecturers competence is a set of knowledge, skills, and behaviours that must be possessed, experienced, and mastered by teachers or lecturers in performing professional duties. The competence includes tasks, skills, attitudes, values, appreciation given in order to have success carrier [18]. It can be interpreted that the competence is a combination of knowledge, abilities, and implementation in carrying out tasks in the field of work. The findings of the study also support theories made by Walton, Panggabean, Hannon and Robertson who say that competence development will improve the performance of individuals and organizations [19, 20,21].

Motivation effect on lecturer performance with a significant value of 0.001 based on significance value 0.05 or 95\% confidence level can be stated that the partial hypothesis of research proved correct that motivation has the positive and significant effect to lecturer performance. The performance of employees in an organization can be measured through employee motivation. In order to elicit better performance, motivational factors accorded high priority and properly employed as an essential ingredient for organizational progress and survival especially in the current turbulent day operating environment. [22]. The stronger the drive or motivation and enthusiasm the higher the performance. In accordance with the opinion of Jusmin, et al that factors that affect performance is a factor of ability and motivation factors [17]. Lecturer motivation influenced by intrinsic and extrinsic or external factors. External factors that affect them are reward and punishment, while an intrinsic factor is a basic reason, for example, the existence of a regulation that must be obeyed. External motivation as a result of Parfyonova's study that individuals partially understand the demand as the value of an activity but they do not regard it as a personal demand, so they act to avoid feelings of guilt or shame [12]. Intrinsic motivation occurs when task interests drive a person and it does not need to give the external factors [13, 14]. Intrinsic motivation sourced from within individuals [6] and when associated with the order of human needs, it involves higherlevel needs (higher level needs). A fundamental thing that indicates a positive motivation is a remuneration or reward in the form of money. Money concerns people's basic needs. In Maslow's theory, people's basic needs are physiological needs. The fulfilment of physiological needs strongly influenced by the level of income.

The result of the analysis showed that there was a positive and significant correlation between each independent variable that is competence and motivation to lecturer performance. Performance is a function of the interaction between competence, motivation and obsession, which means the three factors interact with each other to produce a performance. The higher the competence and motivation of the lecturer, it is possible to create a high performance on the lecturer. In accordance with Porter and Lawler's opinion that employee performance or performance is supported by three factors: employee motivation or effort, competence and clarity, and role acceptance [23]. 


\section{CONCLUSION AND RECOMMENDATION}

\section{A. Conclusion}

Based on the analysis and discussion in the previous chapter, indicate that the competence and motivation variables partially significant effect on the performance (significant value 0.000 and 0.001 with the trust level of 0.05 or $95 \%$ ) and competence and motivation together significantly influence the performance ( $F$ count 134,806 with a significance level of $0,000(\mathrm{p}<0.05))$.

\section{B. Recommendation}

To the related institutions, the results and findings of the research known that the lecturer's performance is influenced by factors of competence and motivation. Therefore, the competence and motivation of lecturers should always be maintained and improved. On the other hand, further research can be done to find out and develop all related variables that will be developed based on indicators and other items that are also considered to impact on the performance of lecturers. In addition, this research is still done locally, which means that research results are only applied to limited and restricted areas, therefore the scope should be further expanded. Expansion of research with the location of research more broadly, so that conclusion of research result can be generalized, especially on factors that can influence lecturer performance.

\section{ACKNOWLEDGMENT}

We would like to thank the Universitas Negeri Surabaya, lecturers and students of Home Economic Department who have participated in the data collection and all the parties who have helped until this research is completed.

\section{REFERENCES}

[1] Al-Mutairi, A., "Factors Affecting Business Students' Performance in Arab Open University: Case of Kuwait," International Journal of Business and Management, vol. 6, pp. 146-155, 2011.

[2] Kang'ahi, M., Indoshi, F.C., Okwach, T.O. \& Osido, J. Teaching Styles and Learners'. 2012

[3] Akiri, A. A. \& Ugborugbo, N. M. , "Teachers' Effectiveness and Students' Performance in Public Secondary Schools in Delta State," Nigeria,Stud Home Comm Sci, vol. 3, pp. 107-113, 2009.

[4] Adunola, O. An Analysis of the Relationship Between Class Size and Academic Performance of Students,Ego Booster Books, Ogun State, Nigeria, 2011.

[5] Ganyaupfu, E.M.,"Factors Influencing Academic Achievement in Quantitative Courses among Business Students of Private Higher Education Institution," Journal of Education and Practice, vol. 4, pp. 57$65,2013$.
[6] Schacter, J. \& Thum,Y.M., "Paying for High and Low Quality Teaching," Economics of Education Review, vol. 24, pp. 411-430, 2004.

[7] Adediwura, A. A. \& Tayo, B. , "Perception of Teachers' Knowledge Attitude and Teaching Skills as Predictor of Academic Performance in Nigerian Secondary Schools," Educational Research and Review, vol. 2, pp. 165-171, 2007.

[8] Ramsden P. Learning to Teach in Higher Education, Routledge Falmer, New York, 2003.

[9] Le Tran Thach Thao, Chiou-Shu J. Hwang., "Factor Affecting Employee Performance Evidence from Petrovietnam Engineering Consultancy J.S.C," https://www.researchgate.net/file.PostFileLoader.html?id (10 Nopemeber 2017)

[10] Aliya Iqbal, maiya Ijaz, Farah Latif, Nina Mushtaq., "Factor Affecting The Employee Performance: A Case Study of Banking Sector in Pakistan," European Journal of Business and Social Science, vol. 4, pp. 309-318. ISSN: 2235-767x, November 2015

[11] Gastañaduy, K, Herrera, D., \& Lens,W, "Work Motivation and Psychological Well-being of Volunteers and Non-Volunteers." Revista de Orientación Educacional, pp. 37-50, 2014.

[12] Parfyonova N., Employee Motivation, Performance and Well-being: The Role of Managerial Support for Autonomy, Competence and Relatedness Needs. Unpublished Doctoral Dissertasion. University of Hongkong. ProQuest Dissertations and Theses, 2009.

[13] Deci E., Ryan R., Gagne M., Leone D., Usunov J., and Kornazheva B., "Need Satisfaction, Motivation, and Well-being in The Work Organizations of a Former Eastern Block Country," Personality and Social Psychology Buletin, vol. 27, pp. 930-942, 2001.

[14] Pintrich, P. and Schunk, D., Motivation in Education, Englewood Cliffs, N.J.: Merrill, 1996.

[15] McGregor, Douglas M., "The Human Side of Enterprise" in Adventure in Thought and Action, Proceedings of the Fifth Anniversary Convocation of the School of Industrial Management, Massachusetts Institute of Technology, Cambridge, MA, 9 April 1957.

[16] Kang'ahi, M., Indoshi, F.C., Okwach, T.O. \& Osido, J. Teaching Styles and Learner's, 2012

[17] Jasmin A, Said S, Bima MJ, Alam R., "Spesific Determinants of Work Motivation, competence, Organizational, Climate, Job Satisfaction and Individual Performance: A Study Among Lecturers", Journal of Business and Management Science, vol. 4, pp. 53-59, 2016.

[18] Walton, Willmott, H., The Flesible Firm of Human Resoures Development, London School of Economic, London, 2004.

[20] Hannon, Paul D, Dean Patton, Sue Marlow, “Transactional Learning Relationships: Developing Management Competencies for Effective Small Firm Stakeholder Interactions", Education + Training, vol. 42, pp. 237-245, 2000.

[21] Robertson. "NVQa: The Impac of Competence Approaches", Management Development Review, vol. 9, 1995.

[22] Sriekaningsih A, Setyadi D. The Effect of Competence and Motivation and Cultural Organization towards Organizational Commitment and Performance on State University Lecturers in East Kalimantan Indonesia. European Journal of Business and Management. ISSN 22221905 (Paper) ISSN 2222-2839 (Online). Vol.7, No.17, (2015).

[23] Porter, L.W., A Study of Perceived Need Satisfaction in Bottom and Middle Management Job. In Porter, D.E., and P.B. Applewhite. Studies in Organizational Behaviour and Management. New York: International Textbook Company, 1961. 